\title{
"Corporate Social Responsibility" (CSR) Antara Publisitas, Citra, dan Etika dalam Profesi Public Relations
}

\begin{abstract}
Ani Yuningsih
ABSTRACT

The field of PR activities are commonly focused on efforts to build strong brand image, product positioning, advertising, promotion and publicity. In the world of high competition, this strategy is not enough. Many multinational corporate nowadays choose Corporate Social Responsibility (CSR) as new strategy to build positive image and gaining good reputation. The existence of CSR program indicate corporate sense of social responsibility toward public interests. In practice, a tension between corporate need to build image and its consistencies toward moral integrity and social commitment was often found. Corporate often use its CSR program as a momentum of publicity instead of showing a real and genuine interest in community development. Therefore, an understanding to $P R$ values and ethics was needed to plan and implement CSR program.
\end{abstract}

Kata kunci: "Corporate Social Responsibility," etika PR, citra, publisitas

\section{Pendahuluan}

\subsection{Latar Belakang Masalah}

Ketika penulis menuangkan gagasan penulisan makalah ini, nurani kita sebagai bagian dari anggota masyarakat dan organisasi bangsa besar Indonesia sedang tergugat, akankah sebagai akademisi kita berdiam diri menghadapi bencana busung lapar yang memakan korban balita meninggal hingga puluhan orang (karena data birokrat tak pernah akurat)? Bencana Tsunami belum lagi tuntas diatasi, menyusul bencana polio, bencana flu burung, dan kini bencana busung lapar, yang benar-benar menampar muka bangsa ini, mencoreng citra di kalangan berbangsa secara internasional. Mana yang akan lebih dipercaya? Retorika birokrat tentang kemakmuran negeri ini tentang ketahanan pangan bangsa ini, pengiriman putri nan anggun, Artika ke pemilihan Miss Universe, atau berita media massa tentang realitas busung lapar di belahan timur Indonesia?

Berbagai ungkapan ironi dilontarkan oleh kalangan budayawan, ekonom, sastrawan, dokter, politisi, hingga birokrat. Saling hujat dan saling tuding melalui media massa sebagai gaya baru retorika bangsa ini semakin gencar. Namun, berita terakhir realisasi penyelesaian masalahnya belum juga terwujudkan secara nyata.

Sebagai akademisi di bidang Public Relations (PR), sudah semestinya penulis terpanggil untuk 
merenung dan memberikan sumbang pemikiran sesuai dengan disiplin ilmu yang geluti. Konsep good governance, community development, dan yang paling akhir corporate social responsibility (CSR) telah didengungkan, namun apakah konsep yang begitu sakral itu hanya berada di tataran wacana, sehingga bencana busung lapar yang mestinya dapat dihindarkan menjadi marak dan merambah sejauh ini? Jangan-jangan konsepkonsep sakral tadi hanya menjadi bahan retorika atau komoditas seminar yang berdaya jual tinggi?

CSR adalah tanggung jawab sosial perusahaan/ lembaga, baik pemerintah maupun swasta, untuk membangun dan membantu masyarakat di mana perusahaan/lembaga tersebut berada.

Kesenjangan antara si kaya dengan si miskin, ketidakberdayaan pemerintah untuk menangani masalah sosial-ekonomi masyarakat, peningkatan daya kritis dan kontrol sosial masyarakat, anti korporasi yang busuk, tuntutan akan transparansi, dan harapan-harapan akan milenium yang akan datang, berdampak pada reputasi perusahaan atau lembaga. Terjadinya bencana busung lapar benarbenar merupakan insiden akibat keteledoran manusia, bukan bencana alam. Artinya, bila "manusia"-nya punya kepekaan sosial dan kepedulian sosial, semestinya bencana itu tidak terjadi. Ini suatu bukti nyata bahwa konsep CSR belum tersosialisasikan apalagi terimpelementasikan di kalangan para pengelola perusahaan, lembaga pemerintahan, lembaga kesehatan, lembaga pendidikan, dan lembaga-lembaga lainnya.

Para praktisi dan teoretisi PR selama ini lebih banyak terbuai oleh upaya-upaya membangun merk, positioning, iklan testimonial, dan aspekaspek promosi atau publisitas PR lainnya yang dipersepsi lebih menggiurkan dan lebih menjanjikan. Padahal, tanpa adanya CSR semua upaya tadi diluluhlantakkan, citra dan reputasi bangsa kini dipertaruhkan, dan semua kalangan mestinya ikut menanggung "dosa" nasional ini.

Terdorong oleh realita tadi, penulis ingin membahas dan menjabarkan lebih jauh mengenai CSR dalam kaitannya dengan profesi Public Relations, dan sebagai alternatif konseptual tentang bagaimana sebaiknya sikap etis para pengelola perusahaan/lembaga, dengan rumusan masalah "Corporate Social Responsibility, antara Publisitas, Citra dan Etika dalam Profesi Public Relations"

\subsection{Identifikasi Masalah}

(1) Bagaimana peranan CSR dalam profesi Public Relations?

(2) Bagaimana keterkaitan antara dengan Publisitas, Citra, dan Etika dalam profesi Public Relations?

(3) Prinsip-prinsip dasar apa yang harus dijadikan pijakan dalam melaksanakan CSR?

(4) Kendala apa saja yang dihadapi dalam pelaksanaan CSR?

\subsection{Tujuan Penulisan}

Melalui tulisan ini diharapkan tumbuh kepedulian dan kesadaran pada para pengelola corporate/lembaga profit maupun nonprofit akan pentingnya CSR dalam menyusun kebijakan manajemen, karena masuknya beberapa pemahaman berikut ini ke dalam ranah kognitif mereka:

(1) Peranan CSR dalam Public Relations.

(2) Keterkaitan yang erat antara CSR, publisitas, dan etika dalam Public Relations.

(3) Prinsip-prinsip dasar CSR sebagai pijakan dalam Kegiatan Public Relations.

(4) Kendala pelaksanaan CSR.

\section{Kerangka Pemikiran}

\subsection{Public Relations}

Public Relations atau humas (hubungan masyarakat) merupakan salah satu metode untuk berkomunikasi secara strategis dengan seluruh constituent organisasi. Seitel (1998), dalam Sutisna, mengatakan bahwa setiap organisasi memiliki hubungan masyarakat, baik diinginkan ataupun tidak. Humas memengaruhi hampir pada aktivitas semua orang yang berhubungan satu dengan yang lainnya. Setiap dari kita dengan menggunakan cara tertentu atau cara lainnya mempraktekkan humas setiap harinya. 
Beberapa definisi humas dapat dikemukakan sebagai berikut:

(1) Public Relations is any situation, act, or word that influences people

(2) Public Relations is the art of making your company liked and respected by its employees, Its customers, the people who buy from it, the people to whom it sells.

(3) Public Relations is the skilled communication of ideas to the various publics with the object of producing a desired result

(4) Public Relations is finding out what people like about you and doing more of it; finding out what they don't like about you and doing less of it.

(5) Public Relations is the management function which evaluates public attitudes, identifies the policies, and procedures of an organization with the public interest, and executes a program action (and communication) to earn public understanding and acceptance. (Marston, 1979, dalam Sutisna, 2003: 327).

Humas mempunyai peranan penting dalam mengomunikasikan program-program yang ditawarkan perusahaan/organisasi/lembaga.

\subsection{Alat-alat Public Relations}

Meldrum dan McDonald (1995) mengidentifikasi alat-alat Public Relations sebagai berikut:

(1) News generation

(2) Events

(3) Publications

(4) Support for good causes

(5) Expert opinion

(6) Visual Identity

Kotler \& Fox (1995) mengemukakan alat-alat hubungan masyarakat secara lebih lengkap, berkaitan dengan aktivitas humas pada perusahaan/organisasi/lembaga:

(1) Written Material.

Organisasi secara ekstensif menggunakan material tertulis untuk berkomunikasi dengan publik. Misalnya, laporan tahunan, katalog, majalah internal dll.
(2) Audiovisual Material and Software Presentasi organisasi dengan menggunakan media audio visual.

(3) Institutional -Identity Media

Media cetak maupun audiovisual yang digunakan organisasi untuk membentuk identitas organisasi/perusahaan/ lembaga, agar memiliki ciri khas yang unik dan mudah dikenali oleh publiknya. Misalnya, logo, warna, uniform dll.

(4) News

Menciptakan berita yang mengangkat nama baik perusahaan/lembaga

(5) Event

Menciptakan kegiatan atau mengelola peristiwa-peristiwa yang terkait dengan perusahaan/lembaga, sehingga menarik perhatian publik.

(6) Speeches Pidato, narasumber dalam diskusi atau seminar, talk show dll.

(7) Telephone Information Services

(8) Personal Contact

Formulasi Kegiatan Humas, menurut Cutlip and Center, antara lain:

(1) Opinion Research

(2) Press Agentry

(3) Product Promotion

(4) Publicity

(5) Lobbying

(6) Public Affairs

(7) Fund Raising

(8) Special Event Management

Dengan demikian, publisitas termasuk ke dalam kegiatan humas, dalam upaya mengomunikasikan dan menyosialisasikan kebijakan dan kegiatan-kegiatan perusahaan kepada berbagai publik yang terkait. Publisitas yang baik akan melahirkan citra yang baik dan publisitas yang efektifakan sangat ditentukan oleh hubungan Public Relations dengan media massa.

\subsection{Citra sebagai Tujuan Public Relations}

Tujuan public relations adalah membangun, memelihara, meningkatkan, dan mempertahankan citra. 
Jefkins dalam Yulianita (2002) mendefinisikan citra (image) sebagai "the picture in our head." Webster (1993) dalam Sutisna (2003) mendefinisikan citra sebagai "gambaran mental atau konsep tentang sesuatu.” Kotler (1995) mendefinisikan citra sebagai "jumlah dari keyakinan-keyakinan, gambaran-gambaran, dan kesan-kesan yang dipunyai seseorang terhadap suatu objek. Objek dimaksud bisa berupa orang, organisasi dll."

Citra suatu organisasi merepresentasikan nilainilai atau value baik value konsumen, atau pun publik-publik terkait lainnya.

Marston mengungkapkan: "By corporate image, then, we mean simply the mental pictures that people have in their heads about companies and corporation. These mental pictures may come from direct experience. They may be rational or irrational, depending on evidence or hearsay, appear in a infinite number of patterns. The fundamental reality of mental pictures in people's head is evident to all"(Sutisna, 2003: 348).

Citra yang baik dari suatu perusahaan/ organisasi merupakan aset, karena cira memiliki dampak terhadap persepsi publik, dampak terhadap efektivitas komunikasi dan operasional organisasi/ perusahaan dalam berbagai segi.

Gronroos (1990) mengidentifikasi adanya empat peran citra bagi suatu organisasi/ perusahaan/lembaga:

(1) citra menceritakan harapan, artinya memberi publik berbagai hal yang bisa diharapkan dari organisasi/ perusahaan;

(2) citra sebagai penyaring, artinya mempengaruhi persepsi publik ketika menerima berbagai pesan komuikasi dari organisasi./perusahaan/ lembaga;

(3) citra adalah fungsi dari pengalaman dan pengharapan. Artinya ketika publik membangun pengharapan terhadap organisasi/perusahaan, kemudian mendapat penguatan dari realitas pengalaman yang ditemui, maka citra akan semakin kuat, dan berlaku sebaliknya;

(4) citra mempunyai pengaruh penting pada manajemen. Artinya, citra mempunyai dampak internal, citra yang kurang jelas atau kabur akan memengaruhi komitmen para anggota organisasi atau karyawan perusahaan.

Penting untuk disadari bahwa citra itu ada dalam realitas, bukan hanya ada dalam pesan yang dikomunikasikan. Pesan yang disampaikan harus mengandung realitas dan kebenaran. Karena ketika tidak ada konsistensi antara kinerja nyata (reputasi) dengan citra yang dikomunikasikan (impression management semata), maka realitaslah yang akan menang dan tertanam dalam benak publik.

Agar citra yang dipersepsikan publik, baik dan benar, dalam arti ada konsistensi antara citra dengan realitas, citra perlu dibangun secara jujur. Cara yang sudah digunakan secara luas dan memiliki kredibilitas tinggi adalah melalui kegiatan humas atau pubic relations yang profesional.

\section{4 "Value" dan Prinsip Dasar Profesi Public Relations}

Value adalah nilai-nilai utama yang menjadi dasar pijakan atau falsafah perusahaan/lembaga. Setiap perusahaan/lembaga harus memahami, menentukan, dan mengarahkan penciptaan value. Juga harus menetapkan metode pengukurannya, harus mampu mengidentifikasi ranah penciptaan dan penghancuran value. Melalui ini ia akan dapat mengalokasi sumber daya, keuangan, manusia, dan intelektual secara lebih fokus, yaitu bahwa seluruh pengalokasian sumber daya dapat diarahkan ke satu titik tujuan: penciptaan value ketiga stakeholders utamanya. Ketiga stakeholders utama perusahaan atau lembaga yaitu: customer, people, dan share holder (investor)

Menggerakkan dan menghdupkan setiap orang di semua tingkatan organisasi ke arah penciptaan value, akan mengurangi, bahkan membuat sirna persaingan antarbagian yang diakibatkan oleh pluralitas tujuan yang ingin dicapai.

Faktor-faktor yang memiliki dampak pada proses penciptaan dan perusakan value adalah value driver. Value driver mencakup dua bentuk, yaitu value lever dan value risk. 
Value lever adalah value driver yang dapat dikontrol secara langsung oleh perusahaan/ lembaga. Karena dapat dikontrol, perusahaan bisa mengelola dan mengarahkan value driver sesuai misi dan tujuan yang ingin dicapai. misalnya employee compensation, customer satisfaction dll.

Value risk adalah value driver yang tidak dapat secara langsung dikontrol oleh perusahaan/ lembaga. Misalnya iklim bisnis, regulasi pemerintah, dll.

Banyak perusahaan/lembaga yang terlalu fokus hanya pada salah satu value. Misalnya costumer value, pada akhirnya mengalami kegagalan, karena ditinggalkan oleh para karyawan terbaiknya. Perusahaan ini mampu memberikan customer satisfaction dengan menyediakan produk yang lebih murah dengan kualitas yang mungkin lebih baik, tetapi mengorbankan karyawan karena khilangannya. Atau perusahaan fokus pada shareholders (investor) dengan memberikan return yang memuaskan, tetapi ditinggalkan pelanggan, karena harga barang yang terlalu mahal dengan kualitas yang mungkin sama. Herb Kelleher, CEO dan Chairman Southwest Airlines, perusahaan yang berhasil meraih kesuksesan jangka panjang, menyatakan bahwa perusahaannya memiliki komitmen pada karyawannya untuk menciptakan lingkungan kerja yang stabil, dengan kesempatan yang sama untuk belajar, dan pengembanan pribadi (Kertajaya, 2003:634).

Untuk mendorong citra yang positif, berikut ini ada sebelas prinsip dalam hubungan masyarakat yang dukemukakan oleh Steven (1996):

(1) Katakan kebenaran. Setiap informasi yang disampaikan hendaknya berisi kebenaran dan bukan kebohongan

(2) Hubungan masyarakat harus bersifat persuasif (membujuk).

(3) Yakin dengan misi yang akan dicapai.

(4) Mampu membangkitkan imajinasi. Kemampuan membangun imajinasi ini akan menyebabkan daya ingat masyarakat menjadi kuat.

(5) Humas harus dipersiapkan secara matang.

(6) Pekerjaan dan profesi humas harus dilakukan sepenuh hati (dijiwai).
(7) Jadilah pendengar yang baik

(8) Pekerjaan humas bukanlah seperti tukang sulap. Artinya, tidak bermaksud mengubah sikap pubik secara seketika, apalagi dengan menyampaikan pesan yang direkayasa tanpa kebenaran.

(9) Individu yang cerdas, tegas, dan memiliki keinginan serta komitmen yang kuat sangat dibutuhkan.

(10) Individu yang banyak akal, berani, dan suka mengambil risiko tidak diperlukan dalam hubungan masyarakat.

(11) Individu yang haus akan pengetahuan sangat diperlukan sehingga tidak menganggap dirinya tahu segalanya.

\section{5 "Ethical Behaviour" Profesi Public Relations}

Profesi Public Relations menuntut adanya standar perilaku etis bagi para pelakunya, yang dituangkan ke dalam "Kode Etik Profesi Humas." Kode etik tersebut, antara lain, mengemukakan adanya nilai-nilai:

- Fairness

- Accuracy

- Honesty

- Professional conduct

- Truthfull dll.

Berdasarkan standar nilai-nilai yang dituangkan dalam penegakan good corporate governance, setiap perusahaan perlu melakukan tiga hal:

(1) Adil (fair) kepada seluruh stakeholders (tidak hanya kepada shareholders).

(2) Proaktif, berperan sebagai agent of change dalam pemberdayaan masyarakat di daerah operasi perusahaan yang bersangkutan.

(3) Efisien, berhjati-hati dalam pengeluaran biaya yang sia-sia, terutama untuk penyelesaian masalah yang timbul dengan stakeholder (fokus di daerah operasi) (Ridwan Nyak Baik, 2005).

Beberapa perilaku pelaku Public relations yang negatif, antara lain:

(1) Mengirimkan Press Release yang salah atau 
menyesatkan (dengan materi yang direkayasa)

(2) Menunda-nunda berita jelek tentang organisasinya

(3) Berbohong pada wartawan dan karyawan

(4) Menutup-nutupi sesuatu

(5) Menjelek-jelekkan sesama praktisi PR lainnya

(6) Menutupi dampak negatif (efek samping) dari produk perusahaannya

\section{6 "Community Relations" sebagai Landasan CSR}

Komunitas adalah sekelompok orang yang hidup di tempat yang sama, berpemerintahan sama, dan mempunyai kebudayaan dan sejarah yang umumnya turun temurun. Orang-orang yang hidup dalam komunitas bersama dengan lembagalembaga yang ada di dalamnya memiliki saling ketergantungan yang tinggi. Mereka tidak dapat menikmati kehidupan yang baik tanpa lembagalembaga tersebut. Begitu pula lembaga-lembaga tersebut hanya dapat hidup dengan izin dan dukungan mereka.

Perusahaan/lembaga membantu komunitas dengan menyediakan pekerjaan, gaji yang layak, keuntungan finansial dengan membeli barangbarang dan jasa dari para pemasok lokal, dengan membayar pajak untuk melaksanakan pemerintahan setempat, dll.

Komunitas atau masyarakat berkontribusi dengan menyediakan tenaga kerja yang terampil, personal manajemen, modal untuk investasi, dan menggunakan barang atau jasa yang dihasilkan perusahaan/lembaga.

Karena alasan-alasan inilah maka suatu perusahaan harus menerima tanggung jawab terhadap komunitas di tempat perusahaan itu beroperasi. Tidak hanya menyediakan pekerjaan dan membayar pajak, tetapi juga berperan aktif dalam kehidupan komunitas, menerima kepemimpinan budaya, membantu pendidikan, meningkatkan kesehatan, memberantas pelanggaran hukum, dan bahkan memberikan berbagai sarana untuk rekreasi.

Konsep hubungan komunitas inilah yang kemudian dielaborasi di tataran praktis menjadi community development dan kini melahirkan konsep CSR.

Belum ada panduan yang jelas tentang konsep CSR ini, apakah CSR ini praktek dan realitas yang nyata dari kegiatan PR dalam membangun komunitas, ataukah hanya bagian dari promosi dan publisitas? Apakah CSR berkaitan dengan nilainilai dan perilaku etis profesi public relations? Apakah CSR hanya dilakukan karena adanya desakan dan kebutuhan masyarakat agar perusahaan/lembaga dapat terus tumbuh dan berkembang? Apakah CSR ini hanya muncul sebagai akibat dari kegagalan pemerintah dalam menyelesaikan masalah-masalah kemasyarakatan? Ataukah CSR ini hanya sekadar fenomena baru atau "trend" dalam kegiatan dan program public relations?

Pertanyaan-pertanyaan ini terlontar manakala konsep CSR muncul ke permukaan, dan tentunya membutuhkan diskusi, klarifikasi, dan elaborasi lebih lanjut baik dari kalangan praktisi maupun teoritisi public relations.

Holme and Watts dalam Ananto (2005) mengemukakan bahwa CSR tidak lain adalah konsep lama dalam kemasan baru dari para profesonal PR: "CSR is the continuing commitment by business to behave ethically and contribute to economic development while improving the quality of life of the workforce and their families as well as the local community and society at large."

Istilah lain bagi CSR: etika business; good corporate citizenship, tanggung jawab sosial perusahaan yang berkesinambungan, dll.

Perusahaan melaksanakan dan mematuhi hukum, budaya, etika bisnis, dan harapan -harapan masyarakat lainnya dalam menjalankan bisnis.

Isu-isu yang tercakup dalam CSR:

(1) Lingkungan hidup

(2) Etika bisnis

(3) Investasi pengembangan masyarakat

(4) Lingkungan kerja

(5) Tata laksana perusahaan (governance)

(6) Hak asasi manusia

(7) Produk (berkualitas dan tidak berefek samping)

(8) Segala aspek perusahaan dengan segala akibatnya 
Contoh kegiatan CSR:

(1) Reklamasi dan perlindungan lingkungan

(2) Pelatihan dan pendidikan

(3) Bantuan keuangan untuk menyelesaikan masalah social

(4) Perlindungan Keselamatan Kerja

(5) Pengujian Kadar Zat kimia dalam produk (bagi tes kesehatan)

(6) Penyuluhan tentang standard kesehatan

(7) Relokasi tempat usaha

(8) Konseling untuk korban narkotika dan minuman keras

(9) Pengembangan usaha kecil local

Contoh kegiatan lainnya:

(1) Charitable donations

(2) Giving back to society

(3) Developing parthnership with NGOs

(4) Ethical funds/ethical investment

(5) Human rights

(6) Educational institusional programs

\section{Pembahasan}

\subsection{Peran CSR sebagai Pendongkrak Reputasi dan Citra Perusahaan/ Lembaga}

Bagi perusahaan/lembaga/organisasi, reputasi dan citra korporat merupakan aset yang paling utama dan tak ternilai harganya. Oleh karena itu segala upaya, daya, kreativitas, dan biaya dikeluarkan untuk memupuk, merawat, serta membina dan mengembangkannya. Salah satu aspek penting yang merupakan unsur pembentuk citra adalah tanggung jawab sosial (CSR) dan penegakan good corporate governance (GCG)

Berdasarkan data dan pengalaman perusahaan yang menjalankan CSR, terbukti berhasil secara positif meningkatkan performance dan keuntungan dalam perkembangan perusahaannya. Contoh Sampoerna, Djarum, Exxon Mobile, Astra, dll.

Managing reputation atau mengelola reputasi perusahaan/lembaga tidak akan berdampak jangka panjang tanpa menyertakan aspek lingkungan, aspek internal stakeholder dan shareholder lainnya.

Sebagai contoh, apakah Anda akan mempercayai dan tetap mendukung perusahaan yang operasionalnya jelas-jelas memberikan dampak negatif terhadap lingkungan? Apakah Anda akan tetap mendukung perusahaan yang membiarkan karyawannya sakit/meninggal karena kecelakaan kerja? Apakah Anda akan memercayai pimpinan/birokrat yang membiarkan rakyatnya mati karena busung lapar?

Reputasi dibangun atas kepercayaan dan dukungan masyarakat. Kredibilitas perusahaan/ lembaga tidak akan tumbuh dengan sendirinya, tanpa adanya upaya meyakinkan dan tulus dari perusahaan untuk berempati terhadap kesulitankesulitan yang dihadapi komunitas di mana ia berada, dan berkiprah secara langsung dan nyata untuk turut serta memberikan jalan keluarnya. Pelaksanaan program CSR harus dilakukan secara terpadu dan komprehensif dalam setiap gerak langkah perusahaan, terkait dengan tanggung jawab sosial di masa lalu, sekarang, dan masa mendatang.

Pola hubungan yang serasi dengan masyarakat akan sangat menguntungkan perusahaan/lembaga dalam mempertahankan atau mengelola reputasi. Melalui CSR manajemen perusahaan/lembaga dituntut untuk mengintegrasikan kepentingan bisnis dengan kepentingan sosial.

Sebagai suatu entitas bisnis dalam era pasar bebas ini perusahaan dituntut mengintegrasikan CSR dalam setiap aspek kegiatannya. Ini, antara lain, disebabkan adanya pergeseran nilai dan budaya yang diadopsi dari budaya Barat, sehingga kini orang atau karyawan tidak lagi loyal kepada perusahaan, tetapi kepada profesi.

Sekjen PBB, Kofi Annan pada hari Selasa kemarin (14 Juni 2005) bertemu dengan Presiden Perancis Jacques Chirac untuk memperkuat kampanye "global compact", yaitu istilah yang diberikan bagi sekumpulan aturan yang disusun PBB soal etika bisnis yang layak diterapkan pada perusahaan multinasional yang berbisnis di negara berkembang. Aturan tersebut, antara lain, soal pentingnya korporasi memberikan penghargaan 
pada HAM (hak asasi manusia) dan tidak melakukan pelanggaran HAM. Komponen lainnya, menyangkut standar ketenagakerjaan, soal tanggung jawab sosial lingkungan hidup, penggunaan teknologi ramah lingkungan, dan soalanti korupsi, termasuk pemerasan dan penyuapan.

Dengan demikian menjadi keniscayaan bagi perusahaan untuk memberikan value added bagi para karyawan dan lingkungan sosialnya, tidak hanya value added bagi costumer dan investornya semata yang diwujudkan dalam kegiatan CSR.

\subsection{Keterkaitan antara CSR dengan Publisitas, Citra, dan Etika}

Publisitas adalah usaha Public Relations untuk mengomunikasikan kegiatan dan kebijakan perusahaan melalui berbagai event penting yang menarik perhatian media massa, sehingga diliput dan disebarluaskan secara gratis (tanpa menyewa media), yang pada gilirannya menanamkan citra tertentu tentang perusahaan/ lembaga di kalangan publiknya. CSR, karena kegiatannya berlandaskan pada moral dan etika, sebaiknya tidak dilakukan semata-mata demi memperoleh publisitas, tetapi demi untuk tanggung jawab sosial itu sendiri. Namun, bila tanpa direkayasa, kegiatan-kegiatan tersebut kemudian ter-"publisitas"-kan, itu hanyalah kebetulan semata.

Publisitas pada dasarnya memanfaatkan berbagai event, atau peristiwa penting, baik peristiwa (event) media massa yang sengaja diciptakan, event alamiah yang terjadi dengan sendirinya (seperti bencana alam), maupun event accidental (tiba-tiba terjadi).

Namun, karena masyarakat kini semakin kritis dan peka, maka untuk kegiatan CSR sebaiknya seorang PR profesional tidak menyusun strategi, baik secara "terbuka" ataupun "diam-diam", untuk menjadikannya ajang promosi. Karena akan mengurangi dampaknya yang significant dalam membangun citra perusahaan/lembaga.

Citra atau image perusahaan/lembaga yang baik dan langgeng adalah yang konsisten dengan realitas pengalaman publik ketika mengadakan kontak langsung maupun tidak langsung dengan perusahaan. Realitas pengalaman yang refleks dan spontan akan lebih dipercaya dibandingkan "manipulasi" pesan komunikasi secanggih apa pun. CSR berdasarkan karakteristiknya yang berlandaskan tanggung jawab etis, akan lebih dipercaya dibandingkan pesan promosi, iklan, dan upaya upaya "marketing" lainnya. Oleh karena itu, CSR berkaitan erat dengan upaya membangun, memelihara, dan mempertahankan citra Perusahaan/Lembaga.

Wacana etika atau moral harus difahami tidak hanya semata-mata sebagai pemahaman tradisional tentang bagaimana mempertahankan aspek normatifnya, tetapi sebaiknya memperhatikan aspek lain yang terlibat dalam pembentukan sikap dan tindakan manusia. Dalam perspektif yang lebih luas, etika terkait erat dengan "cara berpikir" manusia. Jika cara berpikir seseorang berbeda, maka akan berbeda pula keseluruhan pengalaman hidupnya. Ia tidak hanya akan berperilaku berbeda, tetapi juga memiliki pikiran, perasaan, sikap, dan keinginan yang berbeda. Tindakan etis manusia tidak dapat dipisahkan dari cara berpikirnya, tindakan etis merefleksikan atau mempresentasikan cara berpikir manusia. Perbedaan standar etis ini melahirkan perdebatan dan kesepakatan tentang ukuran standar keberhasilan CSR.

Hal-hal yang sedang diperdebatkan dan kesepakatan-kesepakatan yang dihasilkan, antara lain:

(1) Akuntabilitas sosial, yaitu standar yang menjelaskan tentang akuntabilitas sosial, sehingga perusahaan dapat menyusun atau membuat, mempertahankan, dan melaksanakan kebijakan dengan cara-cara tertentu agar perusahaan dapat mengontrol pelaksanaannya. Misalnya: pekerja kanak-kanak, diskriminasi, pemecatan karyawan, jam kerja, keselamatan kerja, kebebasan berserikat, dan sistem manajemen.

(2) Accountability: Standar akuntabilitas yang dikeluarkan tahun 1999, yang digunakan untuk menyusun proses interaksi dengan stakeholders, yaitu: Indikator, sistem pelaporan, target untuk mengukur kinerja perusahaan dalam berinteraksi secara efektif dengan para stakeholder. 
(3) OECD Giudelines for multinational enterprises: Guodelines yang direkomendasikan pemerintah kepada perusahaan-perusahaan multinasional (sifatnya sukarela dan tidak mengikat), isinya menekankan supaya perusahaan mematuhi aturan-aturan, norma, dan budaya setempat di negara tempat perusahaan tsb beroperasi.

(4) Asian-Pacific Economic Cooperation (APEC), dalam Code of Conduct-nya menyebutkan bahwa APEC adalah organisasi internasional yang utama guna mempromosikan perdagangan bebas dan kerjasama ekonomi di antara 21 negara anggotanya.

(5) The Caux Round Table (CRT), mengeluarkan "Principle for Business", sebuah dokumen yang menekankan standar dunia tentang etika dan perilaku perusahaan yang bertanggung jawab. Antara lain mencakup:

(a) Implikasi sosial yang diakibatkan oleh operasional perusahaan terhadap masyarakat setempat.

(b) Patuh kepada aturan-aturan dan etika.

(c) Mendukung perjanjian perdagangan multi lateral.

(d) Tidak melakukan penyogokan.

(e) Pencucian Uang dan Perilaku korup lainnya.

(6) The Keidanren Charter for Good Corporate Behavior berasal dari Nippon Keidanren, berisi pernyataan bahwa perusahaan, meskipun sebagai lembaga ekonomu yang bertujuan mendapatkan laba melalui persaingan yang sehat, juga secara keseluruhan harus berguna bagi masyarakat.

Terlepas dari berbagai upaya untuk menjembatani perdebatan standar etika melalui berbagai kesepakatan tersebut, CSR memang terkait erat dengan etika dan moral para pengelola perusahaan/lembaga, di belahan manapun ia berada.

\subsection{Prinsip-prinsip Dasar dalam Melaksanakan CSR}

Ada lima prinsip CSR:

(1) Ethical values

Nilai-nilai etislah yang dijunjung, bukan semata-mata sebagai ajang promosi, tapi terdapat unsur informasi dan edukasi, juga bukan persuasi.

(2) Compliance with legal requirements Kepatuhan terhadap aturan dan perundangundangan yang berlaku

(3) Respect for people

Tanggung jawab terhadap karyawan menyangkut safety job , job satisfactions, dan menghargai orang-orang dalam berbagai jenis publik (memanusiakan manusia)

(4) Respect for community

Tanggung jawab terhadap masyarakat, misalnya penggantian lahan secara proporsional dll

(5) Respect for Environments

Tanggung jawab terhadap kelestarian lingkungan, misalnya: dampak industri dan limbah, dampak terhadap kesehatan lingkungan, dll

Tahapan Pelaksanaan CSR sebagai strategi dan langkah nyata komitmen perusahaan:

(1) Menyusun pernyataan tentang misi, visi dan nilai-nilai.

(2) Menentukan tujuan dan sistem manajemen yang berbasis CSR: dengan cara mengintegrasikan CSR ke dalam nilai-nilai dan budaya perusahaan (ini akan tercermin dalam setiap keputusan perusahaan).

(3) Komitmen CSR harus berada pada manajemen puncak, sehingga pelaksanaannya bisa konsisten dan terus menerus.

Jadi, pelaksanaan CSR oleh perusahaan berkaitan langsung dengan peningkatan kinerja perusahaan (corporate performance) dan peningkatan reputasi perusahaan (Corporate Reputation)

Kunci kerjasama perusahaan dengan komunitas (community)

(1) Sharing informasi secara terbuka.

(2) mendengarkan dan mengakomodasi perhatian, dengan penekanan pada parameter komersial dan regulasi.

(3) Saat pilihan/usulan alternatif dari komunitas tidak dapat diakomodasi, perusahaan harus meyakinkan mengapa hal tsb tidak dapat 
dilakukan. (Misalnya karena terlalu besarnya biaya bagi pilihan tersebut)

\subsection{Kendala Pelaksanaan CSR}

(1) Masih banyak perusahaan/lembaga yang mempersepsi kegiatan CSR secara keliru, yaitu mendukung CSR semata-mata sebagai bagian dari promosi.

(2) Rendahnya antusiasme dari manajemen terhadap kegiatan CSR.

(3) Banyak dilakukan oleh perusahaan/lembaga yang justru tidak disukai atau menghasilkan produk yang berdampak negatif(seperti rokok, minuman keras, dll)

(4) Banyak perusahaan yang secara membabi buta men-support CSR, sehingga pada akhirnya membuat perusahaan collapse

Terdapat tujuh salah persepsi terhadap humas dalam manajemen (Joseph F. Awad: The Power of Public Relations)

(1) Functional myopia. Tidak mampu melihat fungsi Public Relations yang sebenarnya dalam suatu proses manajemen. Persepsi ini terlihat dalam sikap para pengambil keputusan sbb:

(a) Siapapun dapat melakukan pekerjaan humas. Jadi buat apa menggaji orang khusus untuk mengerjakan itu?

(b) Kegiatan PR dilakukan dengan asal-asalan.

(c) Meletakkan PR dalam posisi rendah dalam organisasi.

(d) Menganggap PR hanya sebagai unit Pub licity atau Event Organizer.

(2) The faucet philosophy. Berpaling pada humas kalau lagi saat kritis atau saat diperlukan saja

(3) The hysteron proteron approach. Menganggap bahwa humas tidak perlu melakukan riset.

(4) Local anesthesia. Sering menganggap bahwa permasalahan yang timbul dalam organisasi hanya masalah internal yang berdampak lokal. Padahal dengan kemajuan teknologi setiap masalah berdampak luas (internal dan eksternal)
(5) Good News Neuresthenia. sikap yang bersandar pada "Kita percaya bahwa melalui informasi publik yang lengkap dan padat segala hal akan berjalan positif dan baik."

(6) The one shot communication tic. Menganggap berkomunikasi cukup sekali atau seadanya. Padahal kita tahu bahwa pengulangan sangat diperlukan dalam komunikasi.

(7) The shadow delusion. Sikap yang bersandar pada "Low profile philosophy" (filsafat low profile)

\section{Penutup}

\subsection{Kesimpulan}

Pola hubungan yang serasi dengan masyarakat akan sangat menguntungkan perusahaan/lembaga dalam mempertahankan atau mengelola reputasi. Melalui CSR, manajemen perusahaan/lembaga dituntut untuk mengintegrasikan kepentingan bisnis dengan kepentingan sosial. Oleh karena itu, segala upaya, daya, kreativitas, dan biaya dikeluarkan untuk memupuk, merawat, serta membina dan mengembangkan reputasi dan citra perusahaan. Salah satu aspek penting yang merupakan unsur pembentuk citra adalah tanggungjawab sosial (CSR) dan penegakan good corporate governance (GCG).

Stakeholder dan shareholder adalah duta penting bagi perusahaan dalam membangun kredibilitas dan reputasi di kalangan publik, hal ini terefleksikan dalam kepercayaan dan dukungan komunitas terhadap perusahaan/lembaga.

CSR, karena kegiatannya berlandaskan pada moral dan etika, sebaiknya tidak dilakukan sematamata demi memeroleh publisitas, tetapi demi untuk tanggung jawab sosial itu sendiri. Namun, bila tanpa direkayasa kegiatan-kegiatan tersebut kemudian ter-"publisitas"-kan itu hanyalah kebetulan semata.

Citra atau image perusahaan/lembaga yang baik dan langgeng adalah yang konsisten dengan realitas pengalaman publik ketika mengadakan kontak langsung maupun tidak langsung dengan 
perusahaan. Realitas pengalaman yang refleks dan spontan akan lebih dipercaya dibandingkan "manipulasi" pesan komunikasi secanggih apa pun. CSR berdasarkan karakteristiknya yang berlandaskan tanggung jawab etis, akan lebih dipercaya dibandingkan pesan promosi, iklan, dan upaya upaya "marketing" lainnya.

Oleh karena itu, CSR berkaitan erat dengan upaya membangun, memelihara, dan mempertahankan citra perusahaan/lembaga.

Kendala Pelaksanaan CSR, antara lain:

(1) Masih banyak perusahaan/lembaga yang mempersepsi kegiatan CSR secara keliru, yaitu mendukung CSR semata-mata sebagai bagian dari promosi.

(2) Rendahnya antusiasme dari manajemen terhadap kegiatan CSR.

(3) Banyak dilakukan oleh perusahaan/ lembaga yang justru tidak disukai atau menghasilkan produk yang berdampak negatif (seperti rokok, minuman keras, dll)

(4) Banyak perusahaan yang secara membabi buta men-support CSR, sehingga pada akhirnya membuat perusahaan collapse.

\subsection{Saran}

(1) Kita tidak akan bisa membangun perusahaan/ lembaga yang besar dan sukses tanpa kemakmuran dan kesuksesan publik-publik yang terkait. Oleh karenanya, harus ada proporsi yang seimbang antara keuntungan bagi perusahaan dengan keuntungan bagi publik internal maupun eksternal.
(2) Komitmen CSR harus dimotori oleh pimpinan puncak, dan didukung seluruh anggota lembaga/organisasi. Dengan demikian, posisi PR sebagai penggagas dan pelaksana CSR harus benar-benar strategis di antara keduanya.

(3) Perguruan Tinggi dapat menjadi mitra dalam pelaksanaan CSR oleh berbagai perusahaan/ lembaga. Dengan demikian, prinsip CSR itu sendiri harus menjadi integritas dari kepribadian akademisi.

\section{Daftar Pustaka}

Ananto, Elizabeth G. 2005. "Corporate Social Responsibility, Numeric or Rhetoric.” Makalah. Jakarta: Trisakti.

Kertajaya, Hermawan. 2003. On Marketing, Jakarta: Gramedia.

Moore, Frasier. 2000. Hubungan Masyarakat; Prinsip, Kasus dan Masalah. Bandung: Remadja Rosda Karya.

Nyak Baik, Ridwan. 2004. Koalisi Dominan, Refleksi Kritis atas Peran dan Fungsi Public Relations dalam Manajemen. Jakarta: Perhumas.

Sutisna. 2003. Perilaku Konsumen \& Komunikasi Pemasaran. Bandung: Remadja Rodakarya.

Abdullah Amin. 2002. Antara Al Ghazali dan Kant; Filsafat Etika Islam. Bandung: Mizan. 
